Animal Health Research Institute, Assiut Lab.

\title{
SOME BACTERIOLOGICAL STUDIES ON SUB CLINICAL MASTITIS IN CATTLE AND ITS RELATION TO CHANGES IN THE MILK PROTEIN ELECTROPHORETIC PATTERN
}

(With 7 Tables)

\author{
By \\ EMAN M. ABDEL-NASER; M.F. HUSSIEN \\ and KH.A.S. EL-KHABAZ \\ (Received at 17/8/2010)
}

بعض الدراسات البكتريولوجية لمرض التهاب الضرع الخفى فى الأبقار وعلاقته بالفصل الكهزبى لبروتينات اللبن

إيمان محد عبد الناصر ، محمود فرغلى حسين ، خالد أحدد سبي الخباز

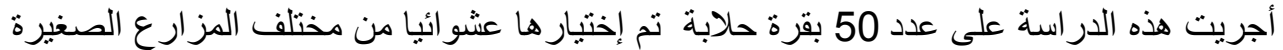

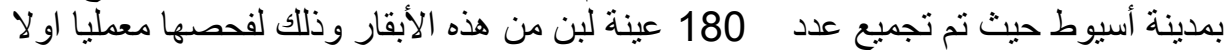

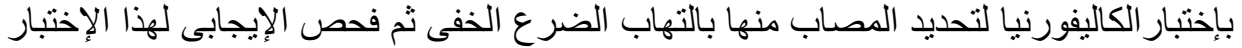

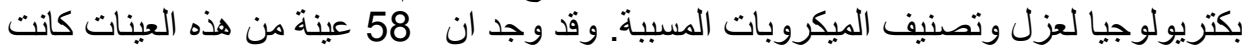

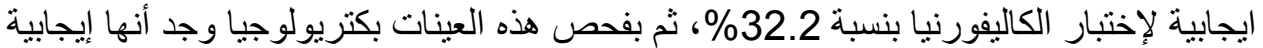

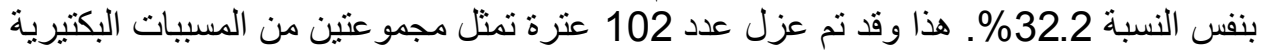

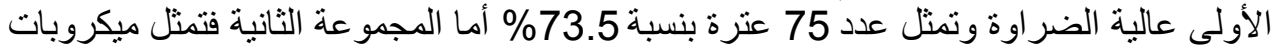

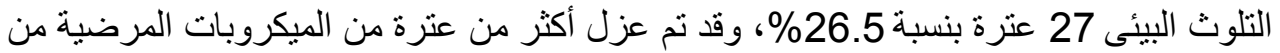

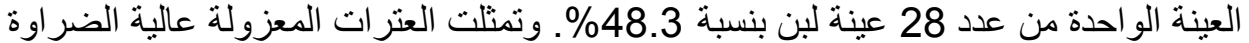

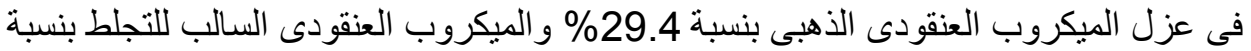

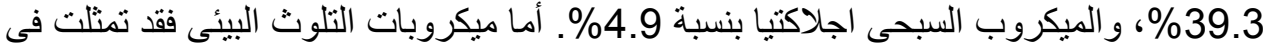

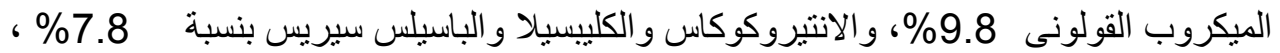

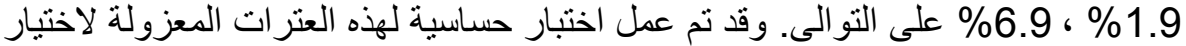

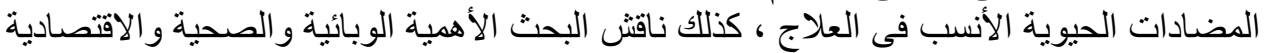

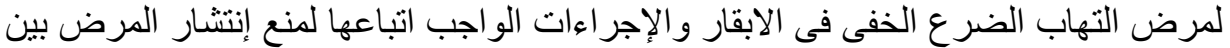

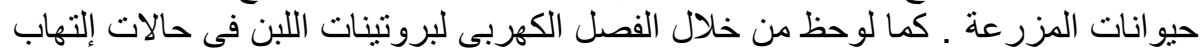

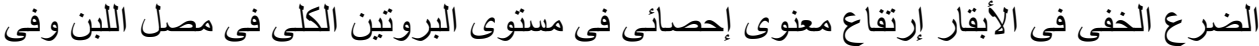

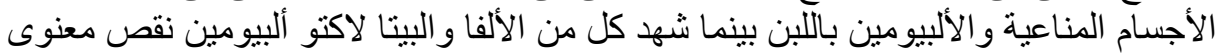

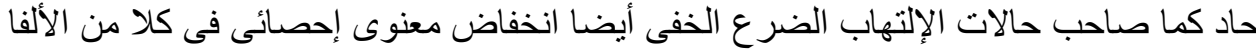
كازين و البيتاكازين و الكباكازين.

Key words: Sub clinical mastitis, bacteriology, milk protein, electrophoresis. 


\section{SUMMARY}

This study was conducted on 50 dairy cows, which were randomly collected from different smallholder farms in Assiut city. 180 milk samples representing 50 dairy cows under test were firstly screened for the presence of subclinical mastitis by using California Mastitis Test (CMT); 58 milk samples yield positive results, and all of these were positive for the bacteriological examination. The isolated bacterial strains (102 isolates) including contagious bacteria representing 75 strains $(73.5 \%)$ and environmental bacteria 27 (26.5\%). $48.3 \%$ of milk samples showing mixed infection. The isolated contagious strains were Staph aureus (30 strain), coagulase negative Staph (CNS) 40 strain, Strept agalactia 5, while the environmental bacteria were $E$ coli 10, Enterococcus sp 8, Klebsiella spp 2 and Bacillus spp 7. The electropheritic patteren of milk proteins showed that there were Significant statistical increase in total whey protein, immunoglobulin and albumin in cows' milk samples with sub clinical mastitis. While $\alpha$-lactalbumin, and $\beta$-lactoglobulin showed significant decreased. There were a highly significant decrease in $\alpha$-casein and $к$ casein in sub clinical mastitic samples in comparing with the normal milk. In addition, there were a significant decrease in $\beta$-casein and nonsignificant decrease in $\gamma$ casein milk protein fractions in sub clinical mastitic milk. Recommendations were suggested to eradicate and control subclinical mastitis to decrease the economic losses in lactating dairy cows.

\section{INTRODUCTION}

Bovine mastitis is a complex and economically important infectious disease for dairy cattle throughout the world, which can result in substantial losses due to reduced milk yield, and increase culling rates and veterinary expenses (Miles et al., 1992).

Subclinical mastitis, without any signs of inflammation compared with clinical mastitis, is the main form of the disease, and accounts for the majority of bovine mastitis cases in dairy herds (Oliver et al., 2004)

Sub-clinical mastitis is 3-40 times more common than the clinical mastitis and causes the greatest overall losses in most dairy herds (Schultz et al., 1978).

The identification of subclinically mastitic quarters and cows is of great concern in the control programs to face the spread of infection within and between dairy herds. Li, et al. (2009) found that $28 \%$ of tested quarters having subclinical mastitis. 
The prevalence of subclinical mastitis is known to be influenced by many additional factors, such as husbandry, management, genetics, nutrition and associated metabolic and endocrine changes (WielgoszGroth and Groth, 2003).

More attention has been given for the diagnosis of SCM by indirect test (Joshi, et al., 1976). Bacteriological culture is a test, similar to CMT and somatic cell count (SCC), which are extremely useful tools for monitoring udder health status and for problem- solving (Radostits, et al., 1994). Simply the bacteriological culture of milk is essential to determine the presence and type of pathogens involved in cases of intra-mammary infection (IMI). Bacterial pathogens that cause mastitis are generally classified as either contagious or environmental based upon their primary reservoir and mode of transmission (Makovec and Ruegg 2003). Contagious bacteria, such as Staphylococcus aureus, Strptococcus agalactia, and Corynebacterium bovis, can spread from an infected cow to another one (Abdel- Khalek and Sherbini, 2005). While environmental bacteria, such as: E.coli, Strept uberis, Actinomyces pyogenes, Pseudomonas aeroginosa and other Staphylococcus spp, are commonly present in surrounding environment and may reach the teat end from that source, (Anwer, et al., 2003).

Staphylococcus aureus seemed to be the predominant organism causing subclinical mastitis (Kader et al., 2002). It may predispose the herd for infection by coliform or other pathogens (Ibtisam et al., 1993). Streptococcus agalactiae lives in milk and in the mammary gland, but can survive only for a few hours outside of the mammary gland (Phuektes, et al., 2001).

Subclinical mastitis caused by intramammary infection (IMI) with coagulase-negative staphylococci (CNS) is common in dairy cows and may cause herd problems (Thorberg et al., 2009).

The identification of subclinically mastitic causing pathogens and their antimicrobial sensitivity testing are important points in the implementation of control programs (Dhakal et al., 2007).

Detection and evaluation of proteins in milk during the course of mastitis are important to elucidate the pathologic mechanism of bovine mastitis (Kato et al., 1989). Electrophoresis has played an important role in the study of milk proteins and has been an integral part of research on the genetic variants of the major proteins components of milk. Indeed, the designations of caseins are derived from electrophoretic analysis and minor caseins components were discovered by electrophoresis (Kostyra, 1990). 
Bovine milk contains 3.0-3.5 \%( w/v) protein (Cole, 1986). Caseins are 2.4-2.8\% of fluid milk and exist in milk as a micelle containing the four casein types: $\alpha$ s1- as2- $\beta$ and k-casein (Kostyra, 1990). Whey proteins are serum albumin, $\alpha$-lactalbumin, $\beta$ Lactoglobulin, and immunoglobulin.

Microbial toxins and enzymes from damaged cells cause injury of secretary cells (Kitchen, 1981). Therefore, the ability of the mammary epithelium to synthesize and secrete the major specific milk constituents is reduced (Fox et al., 1985 and Eberhart et al., 1987). While the secretion of other proteins like lactoferrin is simultaneously upregulated (Schmitz et al., 2004). The concentration of caseins is reduced in infected quarters due to reduced secretion and due to destruction by blood-borne proteases like plasmin (Politis et al., 1992).

Aim of the work: To study the prevalence of subclinical mastitis between cattle in Assiut governorate and to determine the most prevalent causative agents, also studying the relationship between different bacterial causes of subclinical mastitis and the changes occur in milk protein fractions.

\section{MATERIALS and METHODS}

\section{Animals:}

A total of 50 dairy cows, were randomly selected from different smallholder farms at Assiut governorate. The udder and teats of the selected cows were physically and clinically investigated to exclude the clinical mastitis, all animals in all farms were hand milked, twice daily.

\section{Milk Samples:}

Udders and teats of the selected cows were thoroughly washed and dried with sterile clean towel and disinfected with $70 \%$ alcohol. The first milking streams were rejected and $20 \mathrm{ml}$ of milk / each quarter was collected in sterile screw capped bottle. The collected samples were divided into three portions, one portion was subjected to California Mastitis test (CMT), another was subjected to bacteriological examination and about $10 \mathrm{ml}$ of milk / each quarter were used for milk separation into milk serum (whey) and Casein.

\section{Screening test:}

A total of 180 milk samples were subjected to California Mastitis test (CMT) according to Schalm et al. (1971) for detection of sub clinical mastitis. CMT scored from 1 to 5 corresponding to no reaction, trace, mild reaction, moderate reaction and strong reaction, respectively. The positive samples were subjected to bacteriological examination and electrophoresis of milk protein. 


\section{Bacteriological Examination:}

The milk samples were incubated for $18-24$ hours at $37^{\circ} \mathrm{C}$, and 10 $\mathrm{ml}$ of milk samples were transferred into sterile small centrifuge tubes. The tubes were centrifuged at $3000 \mathrm{rpm}$ for 20 minutes, and then the cream and the supernatant were discarded to obtain sediment, then a loop full from milk sediment was streaked onto Azid blood agar plate (Cruickshank, et al., 1975) and a loopfull also was inoculated into nutrient broth (Diffco), $\mathrm{Na} \mathrm{Cl}$ broth $10 \%$, MacConkey broth (Oxide). The previously inoculated tubes were incubated at $37{ }^{\circ} \mathrm{C}$ for 24 hours. From the incubated tubes, loopfulls were streaked onto the surface of the nutrient agar, blood agar with 5\% sheep blood, MacConky agar (Oxoid). The inoculated plates were incubated aerobically at $37^{\circ} \mathrm{C}$ for $24 \mathrm{~h}$.

The suspected colonies were identified morphologically by Gram's stain and biochemicaly confirmed according to Quinn, et al. (1994), using catalase and coagulase tests. Identification of Streptococci spp was done by catalase test, hemolytic activity, sodium hippurate hydrolysis, aesculin hydrolysis on blood agar with $0.1 \%$ aesculin. Enterobacteriace were identified biochemically by conventional IMVIC (Indole, Methyl red, Voges Proskauer and citrate utilization) test, Motility, triple sugar iron agar (TST) inoculation, according to (Quinn, et al., 1994; DeBoer and Heuvelink, 2000).

\section{Antibiotic sensitivity testing:}

Antimicrobial susceptibility testing by using disc diffusion standard technique according to Bauer et al. (1966) and Finegold and Martin (1982) was applied. The isolated micro-organisms were tested against Penicillin 10 i.u, Amoxicillin/Clavulinic acid 20/10 mcgm, Chloramephnicol 30 mcgm, Gentamicin $10 \mathrm{mcgm}$, Norfloxacin $10 \mathrm{mcgm}$.

\section{Sample preparation for electrophoresis:}

Fresh warm raw milk was obtained from Holstein cows. Within an hour after milking, milk samples were skimmed by centrifugation at 3000 rpm for $15 \mathrm{~min}$ to remove their creams and cells. Samples were then treated with $0.1 \mathrm{M}$, hydrochloric acid at the controlled $\mathrm{PH}$ of 4.8 for casein precipitation. Treated samples were recentrifuged and the supernatants (Whey) were collected. The casein precipitate was separated from the whey by filtration. The casein fraction was washed with distilled water three times, maintaining the $\mathrm{PH}$ of the water at 4.7 by addition of dilute $\mathrm{HCl}$.

Casein solution was prepared by dissolving $1 \mathrm{~g}$ casein in $100 \mathrm{ml}$ of $100 \mathrm{mM}$ Tris-Hcl buffer (PH 8.0) and heating in a boiling bath for $20 \mathrm{~min}$. The solution was filtrated without cooling and stored at $4{ }^{\circ} \mathrm{C}$ until to be used. Casein solutions must be discarded after 2 days. The total whey 
protein was determined according to Henry, (1969), application of SDSpolyacrylamide gel electrophoresis according to Sambrook, et al. (1989). The protein standard is ranged from $(10-250 \mathrm{KDa})$ BioRad, using methods of Sambrook, et al. (1989).

\section{Statistical Analysis:}

Student's t-test was carried out to find the differences between the results of mastitic and non mastitic milk samples and the results were given as mean $\pm \mathrm{SEM}$.

\section{RESULTS}

Table 1: Udder-quarter level prevalence of subclinical mastitis:

\begin{tabular}{|c|c|c|c|c|c|c|c|c|}
\hline $\begin{array}{c}\text { No. of } \\
\text { Quarters }\end{array}$ & \multicolumn{2}{|c|}{$\begin{array}{c}\text { CMT } \\
\text { positive }\end{array}$} & \multicolumn{2}{c|}{$\begin{array}{c}\text { Bacteriologically } \\
\text { positive }\end{array}$} & \multicolumn{2}{c|}{$\begin{array}{c}\text { CMT } \\
\text { negative }\end{array}$} & \multicolumn{2}{c|}{$\begin{array}{c}\text { Bacteriologically } \\
\text { negative }\end{array}$} \\
\hline \multirow{2}{*}{180} & No. & $\%$ & No. & $\%$ & No. & $\%$ & No. & $\%$ \\
\cline { 2 - 9 } & 58 & 32.2 & 58 & 32.2 & 122 & 67.8 & 122 & 67.8 \\
\hline
\end{tabular}

Table 2: Prevalence of sub clinical mastitis by using CMT:

\begin{tabular}{|c|c|c|c|c|}
\hline \multirow{2}{*}{ No. of cows } & \multicolumn{2}{|c|}{ CMT positive } & \multicolumn{2}{c|}{ CMT negative } \\
\cline { 2 - 5 } & No. & $\%$ & No. & $\%$ \\
\hline 50 & 27 & 54 & 23 & 46 \\
\hline
\end{tabular}

Table 3: Frequency percentages of single and mixed infection in quarter milk cow's samples

\begin{tabular}{|c|c|c|c|}
\hline & Single infection & Double infections & Triple infections \\
\hline No. & 30 & 18 & 10 \\
\hline$\%$ & 51.7 & 31 & 17.3 \\
\hline
\end{tabular}


Table 4: Prevalence of the isolated subclinical mastitis bacteria from the examined cow's milk samples:

\begin{tabular}{|c|c|c|}
\hline Isolated species & No. & $\%$ \\
\hline Staph aureus & 30 & 29.4 \\
\hline Coagulase Negative Staph (CNS) & 40 & 39.3 \\
\hline Strept agalactia & 5 & 4.9 \\
\hline E coli & 10 & 9.8 \\
\hline Enterococcus spp & 8 & 7.8 \\
\hline Klebsiella spp & 2 & 1.9 \\
\hline Bacillus spp & 7 & 6.9 \\
\hline Total & 102 & 100 \\
\hline
\end{tabular}

Table 5: Results of Antibiotic sensitivity testing of the isolated strains

\begin{tabular}{|l|c|c|c|c|c|}
\hline & Penicillin & $\begin{array}{c}\text { Amoxicillin/ } \\
\text { Clavulinic acid }\end{array}$ & Chloramephnicol & Gentamicin & Norfloxacin \\
\hline $\begin{array}{l}\text { Staph } \\
\text { aureus }\end{array}$ & $50 \%$ & $50 \%$ & $100 \%$ & $75 \%$ & $100 \%$ \\
\hline CNS & $0 \%$ & $25 \%$ & $100 \%$ & $100 \%$ & $100 \%$ \\
\hline $\begin{array}{l}\text { Strept } \\
\text { agalactia }\end{array}$ & $100 \%$ & $100 \%$ & $100 \%$ & $100 \%$ & $100 \%$ \\
\hline E coli & $0 \%$ & $0 \%$ & $100 \%$ & $50 \%$ & $100 \%$ \\
\hline $\begin{array}{l}\text { Klebsiella } \\
\text { spp }\end{array}$ & $0 \%$ & $0 \%$ & $100 \%$ & $100 \%$ & $100 \%$ \\
\hline $\begin{array}{l}\text { Bacillus } \\
\text { spp }\end{array}$ & $0 \%$ & $0 \%$ & $100 \%$ & $100 \%$ & $100 \%$ \\
\hline enterobacter & $0 \%$ & $0 \%$ & $100 \%$ & $0 \%$ & $100 \%$ \\
\hline
\end{tabular}

N.B.: the antimicrobial agents tested were selected on the basis of the actual veterinary practice.

In this study, there were no differences between the different bacterial infections (which causing subclinical infections) in the whey or casein milk protein electropheritic pattern or even the mixed infection.

The percent of protein fractions were significantly different between normal and all bacterial infection $(\mathrm{p}<0.01)$, but there were no differences between different kinds of bacteria so in this study, we comparing between normal and mixed infection causing sub clinical mastitic milk. 
In case of sub clinical mastitis, total whey protein significantly increased $(P<0.05)$ and was accompanied by significant increase $(\mathrm{p}<0.01)$ in the immunoglobulin and albumin content in milk. While both $\alpha-$ lactalbumin, and $\beta$-lactoglobulin were significantly decreased (Table 7).

In this study, there were a highly significant decrease $(\mathrm{P}<0.01)$ in $\alpha$ -casein and $к$ casein in sub clinical mastitis in comparing with the normal milk. Also there were a significant decrease in $\beta$-casein and non significant decrease in $\gamma$ casein milk protein fraction in sub clinical mastitis milk (Table 8).

Table 6: Percentage (\%) of whey-protein fractions in normal and subclinical mastitic milk:

\begin{tabular}{|c|c|c|}
\hline Protein fraction & Normal milk & $\begin{array}{c}\text { Sub clinical } \\
\text { Mastatic milk }\end{array}$ \\
\hline Total whey protein & $14.77 \pm 1.34$ & $17.68 \pm 2.20^{*}$ \\
\hline Immunoglobulin & $14.91 \pm 1.10$ & $19.6 \pm 1.43^{* *}$ \\
\hline Albumin & $7.95 \pm 0.54$ & $15.10 \pm 1.27^{* *}$ \\
\hline$\alpha$-lactalbumin & $26.72 \pm 0.45$ & $22.25 \pm 0.39^{* *}$ \\
\hline$\beta$-lactoglobulin & $54.03 \pm 0.64$ & $31.00 \pm 1.02^{* *}$ \\
\hline
\end{tabular}

* significant at $\mathrm{P}<0.05$., ** Significant at $\mathrm{P}<0.01$.

Table 7: The percentage (\%) of casein-protein fractions in normal and subclinical mastitic milk.

\begin{tabular}{|c|c|c|}
\hline Protein fraction & Normal milk & $\begin{array}{c}\text { Sub clinical } \\
\text { Mastatic milk }\end{array}$ \\
\hline$\alpha$ - casein & $10.68 \pm 0.21$ & $6.26 \pm 0.25^{* * *}$ \\
\hline$\beta$-casein & $8.89 \pm 0.20$ & $7.27 \pm 0.19^{*}$ \\
\hline қ casein & $16.26 \pm 0.09$ & $14.22 \pm 0.18^{* *}$ \\
\hline$\gamma$ casein & $22.20 \pm 0.21$ & $21.48 \pm 0.20$ \\
\hline
\end{tabular}

* significant at $\mathrm{P}<0.05 .,{ }^{* *}$ Significant at $\mathrm{P}<0.01$ and

\section{DISCUSSION}

Cows suffering from subclinical mastitis show no signs, secret apparently normal milk for long time during which infected animal act as potential reservoir for the responsible causative organisms and spread infection among neighboring animals in the herd (Mohamed et al., 1993). 
The California mastitis test (CMT) is used on farms to identify sub clinical mastitis by an indirect estimation of the somatic cell count (SCC) in milk.

Results in Table (1) reveled that the quarter level prevalence of sub clinical mastitis in cows based on the results of CMT and bacteriological examination were $32.2 \%$ (58 out of 180), these results were completely agree with that recorded by Hawari and Al-Dabbas (2008) as they recorded that $31.4 \%$ of tested quarters showed subclinical mastitis, and somewhat similar to the results recorded by Sadek (2008) (29.55\%) and Li et al. (2009) (28\%).

Table (2) estimates the animal prevalence of subclinical mastitis in cow's milk samples based on the results of CMT. Out of 50 cows examined 27 animals (54\%) gave positive results. Similar results were detected by $\mathrm{Li}$ et al. (2009) as they recorded that $54.3 \%$ of tested cows were sub clinically mastitic cases and by Tijare et al. (1999) (57.98\%).A lower percentage was estimated by El-Kholy and Hosein (1990) 16.6\%, while higher percentages were recorded by Sadek (2008) $59.05 \%$ and Sexena et al. (1993) 64\%.

The quarter prevalence of subclinical mastitis in cow's milk samples based on the results of bacteriological examinations was illustrated in Table (1). Out of 180 quarter cow's milk samples examined, 58 (32.2\%) were positive.

These findings were lower than that recorded by Sharma and Rai (1977), Hatem et al. (1984), Saini et al. (1994), Ismail and Hatem (1998) and Nazem and Azab (1998) as they recorded 40.4, 67.74, 76.13, 87.5 and $75.25 \%$ respectively, while these results are higher than that recorded by Ismail and Hatem (1998) 26.5\% and Sadek (2008) 28.5\%. The subclinical mastitis incidence varied widely due to changing management conditions (Radostitis et al., 2000).

CMT field test is a dependable and a reliable perfect test (El-Gamal, 1989 and El-Balkemy et al., 1997). In this study CMT results were agree completely $(100 \%)$ with bacteriological isolation.

Table (3) illustrated that the mixed infection was $48.3 \%$ and the single isolation $51.7 \%$, this finding reflects an idea about the level of environmental bacterial contamination in the herd and demonstrate the complexity of the disease.

Table (4) shows the isolated bacterial strains from the examined subclinical mastitic milk samples, it is revealed that the main isolates were of the contagious type Staph aureus, CNS, Strept agalactia in percentages of $29.41 \%, 39.21 \%$, and $4.9 \%$ respectively. The contagious organisms were well adopted to survive in the udder and usually establish mild subclinical infection for long duration (El-Khodery and Hoedemaker, 2005 and Abdel- 
Khalek and El-Sherbini, 2005) and can spread from infected quarter to another quarters (El-Balkemy et al., 1997). Staphylococci typically colonize the broken skin and can enter the udder through abrasions of the teat (Dhakal, 1997).

Several studies have estimated the prevalence of subclinical mastitis due to Staph aureus and have shown wide variation. The obtained results $29.41 \%$ were similar to that recorded by Janosi and Balty, 2004, and lower than that recorded by (Attia et al., 2003) (80\%) and Shitandi and Kihumbu,2004(45.6\%). Staph aureus and Strept agalactia are commonly isolated from sub-clinical mastitis (Abdel-Khalek and El-Sherbini, 2005) where Staph aureus commonly produce long-lasting infections as it developed sophisticated system to avoid phagocytosis or macrophages (Vanfurth and Van Zwet, 1986).

The importance of coagulae negative Staph as a cause of subclinical mastitis was previously demonstrated by Hodges et al. (1984), Malinowski et al. (1992).

Subclinical mastitis caused by intra-mammary infections (IMI) with coagulase-negative staphylococci (CNS) is common in dairy cows and may cause herd problems. Control of CNS mastitis is complicated by the fact that CNS contains a large number of different species (Shitandi and Kihumbu, 2004).

From Table (4) it is clear that the CNS were isolated from $39.3 \%$ of subclinically mastitic milk samples and this completely agree with Sargeant et al. (2001) who isolate CNS from $40 \%$ of tested samples.

Table (4) illustrate the environmental bacteria (E coli, enterococcus spp, Klebsiella spp, and Bacillus spp) isolated from the subclinically mastitic quarters cows milk samples, these environmental bacteria originate from the surrounding environment including air, soil, water, bedding materials, faecal matter, milking man, and milking utensils (Anwer et al., 2003). The portal of entry into mammary gland for gram negative bacteria is the teat canal.

The most familiar environmental pathogen, E.coli is widely documented to be a sub-clinical mastitis pathogen (Anwer et al., 2003). Its persistence within the mammary environment was of the recurrent quarter's E.coli mastitis and its spread among other quarters and cows may occur during the milking process (Bradley and Green, 2001).

Table (5) showing the results of antimicrobial sensitivity testing, it is clear that the most effective antimicrobial agent are Norfloxacin and chloramephnicol followed by Gentamicin and the least effective one is the penicillin and this is may be attributed to the misuse of penicillin in the 
veterinary practice (incomplete treatment course and under dosing) so resistant strains were developed.

Inflammation of the mammary gland leads to a variety of compositional changes in milk either because of local effects or because of serum components entering the milk and the movement of some normal milk components out of the alveolar lumen into the perivascular space (Harmon, 1994).

Albumin content of milk in sub clinical mastitis was significantly increased compared to the healthy ones. The increase of albumin content during mastitis has been reported in cows (Coulon et al., 2002 and Batavani et al., 2007).

De Wit, 1998, said that the main site of albumin synthesis is in the liver, and the albumin enters the milk by leaking through the epithelial tight junction from the blood stream, while Shamay et al. (2005) found that the extra hepatic synthesis of albumin has been demonstrated in mammary gland epithelial cells, but in lesser amounts than the liver.

The marked increases of albumin in mastitic cows suggest that a major source of the increase in the content of albumin in milk under inflammatory conditions is the mammary gland itself.

Immunoglobulin in mammary secretions is serum- derived or produced in the udder and pass into the milk through the mammary epithelium. The concentrations of immunoglobulin in normal milk are low and depend on the degree of vascular permeability of the udder tissues (Coulon et al., 2002 and Henry et al., 2007). During inflammation this permeability barrier is broken, immunoglobulin concentrations increase in secretions from infected glands.

The increase in milk immunoglobulins may be effective in reducing severity of mastitis (Nickerson, 1985; and Persson, 1992). The major function of immunoglobulins is opsonization of microorganisms for phagocytosis, and they are believed to prevent bacterial adherence to epithelial membranes,inhibit multiplication and neutralize toxins. The decrease in $\alpha$-lactalbumin, $\beta$-lactoglobulin associated with the sub clinical mastitis agreed with results of previous investigations reported by (Ishikawa and Shimizu, 1982). This could be due to both inflammatory damage of the mammary secretary tissues and destruction of the blood milk permeability barriers which restrict and discriminate in transfer of protein from interstitial fluid into milk.

The percentages of $\alpha$ casein, $\beta$ casein, $қ$ casein, and $\gamma$ casein in mastitic samples were lower than those of healthy normal milk. This result may be explained by that milk from mastitic udders exhibits greatly increased proteolytic activity (Le Roux et al., 1995). Plasmin is the most 
important protease in milk from healthy udders but the non-plasmin proteases become more important with increasing severity of udder inflammation. This proteolysis leads to a decrease in the relative proportion of caseins (Auldist et al., 1996, Weinbreck, et al., 2004 and Henry et al., 2007).

\section{CONCLUSION}

Although the CMT is a quick, easy to perform test and accurately identify subclinical mastitic cases it is not specific for specific pathogens.

Identification of the causative agent is an essential step in the application of antimicrobial therapy and herd management.

Infected animals should be identified as rapid as possible as it is the potential source of infection to non-infected animals.

Protein percent of milk serum whey protein, immunoglobulin, and albumin increased during subclinical mastitis. While $\alpha$-casein, қ casein, and $\beta$-casein decreased in sub clinical mastitis.

\section{REFERENCES}

Abdel-Khalek, A. and El-Sherbini, M. (2005): Prevalence of contagious pathogeno of bovine subclinical mastitis and relationship to bacterial and somatic cell counts. $4^{\text {th }}$ Int. Sci. Conf., Mansoura $1-10$.

Anwer, W.; Mohga F. Badawi and Gehan Z. Moustafa (2003): Environmental micro-organisms causing mastitis in dairy cattle reared under different hygienic measures. J. Egypt. Vet. Med. Ass. 63 (1): 161-170.

Attia, E.R.H.; Amal, A. El Rashidy and Metias, K.N. (2003): Comparative study between electric conductivity, Calfornia mastitic test and somatic cell count for rapid diagnosis of subclinical mastitis in lactating cow. The $7^{\text {th }}$ Sci. Cong Egyptian society cattle Diseases, PP. 25-29.

Auldist, M.J.; Coats, B.J.; Mayes, J. and McDowell, G.H. (1996): Effects of somatic cell count and stage of lactation on raw milk composition and the yield and quality of cheddar cheese. Dairy Res. 63: 269-280.

Batavani, R.A.; Asri, S. and Naebzadeh, H. (2007): The effect of sub clinical mastitis on milk composition in dairy cows. Iranian J. Vet. Res. 20: 205-211. 
Bauer, A.W.; Kirby, M.M.; Sherris, J.C. and Turch, M. (1966): Antibiotic susceptibility testing by a standardized single disc method. Am. J. Clin. Pathol. 45: 493-496

Bradley, A.J. and Green, M.J. (2001): Aetiology of clinical mastitis in six somerset dairy herdo. Vet. Rec.; 148 (22): 683-686.

Cole, E.H. (1986): Veterinary clinical pathology. $4^{\text {th }}$. Ed. Philadelphia, W.B.Saunders Co., 362.

Coulon, J.B.; Gasqui, P.; Barnouin, J. and Pomies, D. (2002): Effect of mastitis and related-germ on milk yield and composition during naturally-occurring udder infections in dairy cows. Anim. Res. 51: 383-393.

Cruikshank, R.; Duguid, J.P.; Mormoion, B.P. and Swaim, R.H.A. (1975): The practico of medical microbiology $12^{\text {th }}$ Ed., Vol. Churchill livingstone London, U.K.

DeBoer, E. and Heuvelink, A.F. (2000): Method for the detection and isolation of shiga-toxin producing E-coli J. of Applied Microbiology Symposium Supplement, 88: 133-143.

De Wit, J.N. (1998): Nutritional and functional characteristics of whey proteins in food products. J Dairy Sci. 81: 597-608.

Dhakal, I.P. (1997): Drug selection and use on clinical mastitis in buffaloes at Chitwan Valley of Nepal. Bubalus bubalis, 11: 56-70.

Dhakal, I.P.; Dhakal, P.; Koshihara, T. and Nagahata, H. (2007): epidemiological and bacteriological survey of buffalo mastitis in Nepal. J. Vet. Med. Sci., 69 (12): 1241-1245.

Eberhart, R.J.; Harmon, R.J.; Jasper, D.E. and Spencer, S.B. (1987): Current concepts of bovine mastitis $3^{\text {rd }} E d$. Natl. Mastitis Counc., Inc., Arlington, VA.

El-Balkemy, F.A.; Esmat, M.; Afaf Menazie and Azza N. Farag (1997): Evaluation of screening tests used for detection of subclinical mastitis. $4^{\text {th }}$ Sci. Cong. Egyptian Society for cattle Disease, 7-9 Dec. Assiut, Egypt: 181-191.

El-Gamal, A.M. (1989): Studies on subdinical mastitis among dary farms. M.V.Sc. Thesis. Fac. of Vet. Med. Zagazig Univ.

El-Khodery, S.A. and Hoedemakes, M. (2005): Incidence and type of mastitis in the livestock of Nothern Germany concerning management factors. $4^{\text {th }}$ Int. Sci. Conf., Mansoura, 5-6 April, 973-987.

El-Kholy, A.M. and Hosein, H.I. (1990): Studies on sub clinical mycotic mastitis in cows. Assiut Vet. Med J., 22 (44): 111-115.

Finegold, S.M. and Martin, W.J. (1982): Bailley and Scott's Diagnostic Microbiology. $6^{\text {th }}$ Ed. C.V.Mosoly Co.St. Louis. Toronto, London 
Fox, L.K.; Shook, G.E. and Schultz, L.H. (1985): Factors related to milk loss in quarters with low somatic cell counts. J. Dairy Sci 68: 2100-2107.

Harmon, R.J. (1994): Physiology of mastitis and factors affecting somatic cell counts. J Dairy Sci., 77: 2103-2112.

Hatem, M.E.; Saleh, S.M.; Shelaish, M.A.; Hafez, R.S. and Abozeid, A.A. (1984): Staphylococus aureus Subclinical mastitis in a machinemilked dairy head with refrence to treatment with gentamycin Vet. Med. J., 32 (3): 171-179.

Hawari, A.D. and Al-Dabbas, F. (2008): Prevalence and distribution of mastitis pathogens and their resistance against antimicrobial agents in dairy cows in Jordan. American J. animal \& Vet. Sci., 3 (1):36-39

Henry, H. (1969): Determination of total protein (Hawks clinical chemistry)Lang

Press.38-70.

Henry, O.; Anakalo, S. and Jackin, N. (2007): Effect of mastitis on raw milk compositional quality.J.Vet.Sci.3: 237-242.

Hodges, R.T.; Jones, Y.S. and Holland, J. T. S. (1984): Characterization of staphylocci associatel with clinical and subclinical bovine mastitis. New Zealand Vet. J. 32 (9): 141-145.

Ibtisam, E.; Mohamed; G.E.; Mohamed, G.; Eaud El Own, O.A.O. (1993):

A study on the incidence and etiology of bovine mastitis in sudan $2^{\text {nd }}$ Sci. Cong. Egyptian Society for Cattle Diseases, 5-7 Dec. Assiut, Egypt, 326-332.

Ishikawa, H. and Shimizu, T. (1982): Protein composition of whey from subclinical mastitis and effect of treatment with levamisole. J. Dairy Sci. 65: 653-658.

Ismail, T.M. and Hatem, M.E. (1998): Prevalence of sub clinical mastitis in a dairy cottle herd in the eastern region of Saudi Arabia. Proc. $8^{\text {th }}$ Sci. Cong., Fac. Vet. Med., Assiut Univ., Egypt.

Janosi, S. and Baltay, Z. (2004): Correlations among the somatic cell count of individual bulk milk, result of the California Mastitis test and bacteriological status of the uddes in dairy cows. Acta Vet. Hung. 52: 173-183.

Joshi, S.V.; Prasad, J. and Rekib, A. (1976): Studies on the field diagnosis of SCM. Indian Vet. J. 53 (10): 752-756.

Kader, M.A.; Samad, M.A.; Seha, S. and Taleb, M.A. (2002): Prevalence and etiology of subclinical mastitis with antibiotic sensitivity to isolated organismo among Milch cows in Bangladesh. I. J. D. S., 55, 4: 218-223. 
Kato K.; Mori K.; and Katoh N. (1989): Different protein patterns in normal and mastitic milks as revealed by sodium dodecyl sulfatepolyacrylamide gel electrophoresis. Japans J. Vet. Sci 6:12751278.

Kitchen, B.J. (1981): Review of the progress of dairy science: Bovine mastitis: milk compositional changes and related diagnostic tests. J. Dairy Res., 48, 167-188.

Kostyra, E. (1990): Changes in protein fractions of milk obtained from cows with mastitis caused by Staphylococcus aureus. Preliminary studies. Rocz. Pantsw. Zakl. Hig., 41: 263-268.

Le Roux, Y.; Clin, O. and Laurent, F. (1995): Proteolysis in samples of quarter milk with varying somatic cell counts. 1. Comparison of some indicators of endogenous proteolysis in milk. J. Dairy Sci, 1289-1297.

Li, J.; Zhou, H.; Yuan, L.; He, T. and Hu, S. (2009): Prevalence, genetic diversity, and antimicrobial susceptibility profiles of Staphylococcus aureus isolated from bovine mastitis in Zhejiang Province, China. Journal of Zhejiang University 10(10): 753-760.

Makovec, J.A. and Ruegg, P.L. (2003): Results of Milk Samples Submitted for Microbiological Examination in Wisconsin from 1994 to 2001. J. Dairy Sci. 86: 3466-3472.

Malinowski, E.; Klassowska, A. and Szalbierz, M. (1992): Pathogenicity to the mommary gland of micro-organisms isolated from clinical and subclinical bovine mastitis. Medycyna-Veterynaryina. 18 (10): 467-469.

Miles, H.; Lesser, W. and Sears, P. (1992): The economic implications of bioengineered mastitis control. J Dairy Sci, 75: 596-605.

Mohamed, Ibtisam, E.; Mohamed, G.E. and El-Owni, O.A.O. (1993): A study on the incidence and etiology of bovine mastitis in sudan. Proc. $2^{\text {nd }}$ Sci. Cong. Egyptian society for Cattle Diseases, 5-7 Dec., Assiut. Egypt.

Nazem, A.M. and Azab, M.H. (1998): Detection of opparently normal milk by screening and confirmatory methods. Pro $8^{\text {th }}$ Sci Cong., Assiut Univ., Egypt.

Nickerson, S.C. (1985): Immune mechanisms of the bovine udder: an overview. J. Am. Vet. Med. Assoc., 187: 41-45.

Oliver, S.P.; Gillespie, B.E.; Headrick, S.J.; Moorehead, A.; Lunn, P.; Dowlen, H.H.; Johnson, D.L.; Lamar, K.C.; Chester, S.T. and Moseley, W.M. (2004): Efficacy of extended ceftiofur intramammary therapy for treatment of subclinical mastitis in lactating dairy cows. J. Dairy Sci., 87(8): 2393-2400. 
Persson, K. (1992): Studies on inflammation in the bovine teat with regard to its role in the defense against udder infections. Dissertation, Uppsala, Sweden, 11-17.

Phuektes, P.; Mansell, P.D.; Dyson, R.S.; Hooper, N.D.; Kick, J.S. and Browning, G.F. (2001): Molecular epidemiology of streptococcus uberis isolated from diary cows with mastitis. J. Clin. Microbiol. 39 (4): 1460-1466.

Politis, I.; Barbano, D.M. and Gorewit, R.C. (1992): Distribution of plasminogen and plasmin in fractions of bovine milk. Journal of Dairy Science, 75: 1402-1410.

Quinn, P.J.; Carter, M.E.; Markey, Band Corter, G.R. (1994): Clinical veterinary Microbiology. Walfe publishing, an imprint of mosbyyear book Europe limited.

Radostits, O.M.; Lesl, eK.E. and Fetrow, J. (1994): Hend Health Food Animal Production Medicine. $2^{\text {nd }}$ Ed., Toronto: W. B. Saunders Company, 229-273.

Radostitis, O.M.; Gay, C.C.; Blood, D.C. and Hincheliff, K.W. (2000): Veteninary Medicine. $9^{\text {th }}$ Edn., W. B. Sawndersco Ltd., London.

Sadek, O.A. (2008): Human health risks associated with consumption of milk from subclinical mastitic animals in Assiut governorate. Ph.D thesis, Fac. Vet. Med., Assiut Univ., Egypt.

Saini, S.S.; Sharma, J.K. and Kwatra, M.S. (1994): Prevalence and etiology of sub clinical mastitis among Grossbreed Cows and buffaloes in Punjab. Indian J. Dairy Sci., 47 (2): 103-106.

Sambrook, J.; Fritsch, E.F. and Maniatis, T. (1989): Molecular Cloning. A Laboratory Manual, (second ed.), 18: 47-59.

Sargeant, J.M.; Lesile, K.E.; Shirley, J.E.; Pulkrabek, B.J. and Lim, G.H. (2001): Sensitivity and specificity of somatic cell ount and California Mastitis test for identifying intramammary infection in early loctation. J. Dairy Sci., 84: 2018-2024.

Scalm, O.W.; Crrolle, J. and Jain, N.C. (1971): Bovine mastitis. Lea and Febiger Philadelphia.

Schmitz, S.; Pfaffi, M.W.; Meyer, H.H.D. and Brukmaier, R.M. (2004): Short-term changes of mRNA expression of various inflammatory factors and milk proteins in mammary tissue during LPS-induced mastitis. Domestic Animal Endocrinology, 26: 111-126.

Schultz, L.H.; Brown, R.W.; Jasper, D.E.; Berger, R.W.M.; Natzke, R.P.; Philpot, W.N.; Smith, J.W. and Thomson, P.D. (1978): Current Concepts of Bovine Mastitis. $2^{\text {nd }}$ Ed. The National Mastitis Council, Inc. Washington DC, USA. pp: 6-9. 
Sexena, R.K.; Dutta, G.N.; Borah, P. and Buragohain, J. (1993): Incidence and etiology of bovine subclinical mastitis. Indian Vet. J., 70 (11): 1079-1080.

Shamay, A.; Homans, R.; Fuerman, Y.; Levin, I.; and Mabjeesh, S.J. (2005): Expression of albumin in non-hepatic tissues and its synthesis by the bovine mammary gland. J Dairy Sci., 88: 569-576.

Sharma, S.D. and Rai, P. (1977): Studies on the incidence of bovine mastitis in uttar pralesh II. Sub clinical mastitis. Indian Vet. J., 54 (6): 435-439.

Shitandi, A. and Kihumbu, G. (2004): Assessement of the California mastitis test usage in small holder dairy herds and risk of violative antimiaobila residues $>$ J. Vet. Sci, 5: 5-9.

Thorberg, B.M.; Danielsson-Tham, M.L.; Emanuelson, U. and Persson Waller, K. (2009): Bovine subclinical mastitis caused by different types of coagulase-negative staphylocooci. J. Dairy Sci. 92: 4962-4970.

Tijare, D.B.; Singh, A.K.; Chaturvedi, V.K. and Dhanesas, N.S. (1999): Sensitivity of indirect tests in detection of subclinical mastitis in buffaloes. Indian Vet. J., 76 (10): 912-915.

Vanfurth, R. and Van Zwet, T. (1986): In vitro determination of phagocytosis and intra cellular killing by polymerphonucleas and mononuclear phagocytes. Incited from; Weir DM. and Herzenberg LA., Handbook of Experimental Immunology, Vol. 2, Cellular Immunology Black Scientific publications, Oxford, UK, PP. 36.1-36.24.

Weinbreek, F.; Nieuwenhuijse, H.; Robijn, G.W. and De Kruif, C.G. (2004): Complexation of whey proteins with carrageenan. J. Agric. Food Chem., 11: 3550-3555.

Wielgosz-Groth, Z. and Groth, I. (2003): Effect of the udder health on the composition and quality of quentes milk from block-and white cows. Electron. J. Pol. Agr. U. Anim. Husbandry, 6, Issue 2. http:// www. ejpau. media. pl/ seriesvolume6/ issue2/ animal (astolihtm). 